\title{
RXRB wt Allele
}

National Cancer Institute

\section{Source}

National Cancer Institute. RXRB wt Allele. NCI Thesaurus. Code C51715.

Human RXRB wild-type allele is located in the vicinity of $6 \mathrm{p} 21.3$ and is approximately $7 \mathrm{~kb}$ in length. This allele, which encodes retinoic acid receptor RXR-beta protein, is involved in the mediation of DNA binding and transcriptional regulation pertaining to processes involving the effects of retinoic acid. 